\title{
Caol Reathainn (Mar a Fhuair E an t-Ainm) (with Translation)
}

\section{Author(s): Alexander Carmichael}

Source: The Celtic Review, Vol. 1, No. 1 (Jul., 1904), pp. 32-35

Stable URL: http://www.jstor.org/stable/30069767

Accessed: 27-06-2016 01:05 UTC

Your use of the JSTOR archive indicates your acceptance of the Terms \& Conditions of Use, available at

http://about.jstor.org/terms

JSTOR is a not-for-profit service that helps scholars, researchers, and students discover, use, and build upon a wide range of content in a trusted digital archive. We use information technology and tools to increase productivity and facilitate new forms of scholarship. For more information about JSTOR, please contact support@jstor.org. 


\section{CAOL REATHAINN}

\section{MAR A FHUAIR E AN T-AINM}

\section{Alexander Garmichate}

AIR am airidh, air do na Feinn tighinn dhachaidh bho 'n t-seilg do thaigh Farbheil, aig bonn Farbheinn ann an Ardnamurachan, bha ioghnadh mor orra na mnathan aca fhaotainn cho reamhar, geal, boidheach, oir bha'n t-sealg fior ghann air na Feinn aig an am. Chuir na Feinn rompa gu 'm bitheadh fios aca gu de a bha na mnathan aca faighinn g' an deanadh mar so; agus an uair a dh' fhalbh iad a rithist gus an $t$-seilg dh' fhag iad Conan, fear diubh fhein, aig an taigh, a chum so fhaotainn a mach. Rinn Conan faire agus 's $\theta$ am biadh a bha aca, barr a challtuinn air a bhruich agus iad ag ol an $t$-suigh. Tha e air a radhainn cuideachd, gu 'n robh iad g' an nigheadh fhein leis. Thuig na mnathan gu 'm b' ann g' am faire fein a chaidh Conan fhagail aig an taigh agus bha fearg mor orra.

Anns an oidhche, an uair a laigh Conan a sios gu cadal cheangail iad fhalt ri da stob a chuir iad 's an talamh, air gach taobh de cheann. Chaidh na mnathan an sin a mach gu beul an taighe agus bhuail iad am basan agus dh' eubh iad na creachan le guileag mor gus an do dhuisg iad Conan. Leum Conan air a chois le cabhaig mhoir, ach dh' fhag e pairt de fhalt agus de shoic a chinn ceangailt ris na stuib.

An uair a fhuair Conan na mnathan a stigh, chuir e teine ri fraoch gorm agus ri connadh glas am beul an taighe, a chum agus na mnathan a mharbhadh leis an toit.

Bha na Feinn aig an am so anns an Eilean Sgitheanach, mu choinneamh taigh Farbheil air taobh eile Chaol Reathainn, agus an uair a chunnaic iad an teine agus an toit ag eiridh suas ghlaodh iad gu h-ard a bualadh an lamh chli air clar an aodainn, agus an suilean air an speur. Ruith iad a' sin gu 'n 
cuid mhnathan a thearnadh ach bha 'n caol eadar iad 's an taigh; ach le 'n lannan leum iad an caol ach aon fhearmac Reathainn. Thuit mac Reathainn anns a chaol agus chaidh a bhathadh, agus bho 'n latha sin gus an la 'n diugh lean Caol Reathainn mar ainm ris a chaol.

Fionnachas luath air bantrachd Fheinn,

'S leum gach fear air barr a shleagh

Ach dh' fhag iad mac Reathainn 's a chaol.

$\mathrm{Gu}$ sealbhach thainig na mnathan uile troimhe ach aon no dithis dhiubh, o 'n rinn na Feinn dean-ruith g' an teasruig. Bha na Fiann ann am fearg mhor ri Conan, air son mar a rinn e, agus rug iad air a chum a chuir gu bas. Dh' iarr Conan mar fhabhor gu 'n rachadh an ceann a thoirt dheth le Mac-anLuinn-claidheamb Fhinn mhic Cumhail, nach fagadh fuigheal na dheigh, agus a mhac fhein, an Garabh, ga bhualadh air sliasaid Fhinn. Chaidh so a cheadachadh dha, ach chaidh an toiseach seachd seichean glasa, seachd cuailtean connaidh, agus seachd tirinn de riasg gorm, a chuir air muin sliasaid Fhinn. Chaidh ceann Chonain a leagadh air a sin agus bhuail an Garabh, a mhac fein, an ceann deth le Mac-anLuinn, agus-

Cha bu lionmhoire crois 's an dearna

Na cuislean geairrte an sliasaid Fhinn.

Dh' fheoraich an Garabh dhiubh an sin c' aite an robh na Feinne, oir bha $\Theta$ air dol air a chuthach, agus thubhairt iad ris gu 'n robh iad gu h-iosal foidhe. Ghabh e 'n sin sios gus an do rainig e a' mhuir agus shlachdanaich e a' mhuir gus an do bhath se e fein innte.

\section{LITERAL ENGLISH}

CAOL REATHAINN (KYLE RHEA)-HOW IT GOT THE NAME

ON a certain time when the Feinn had come home from the chase to the house at Farabheil, at the foot of Farabhein in voL. $\mathbf{r}$. 
Ardnamurchan, they were surprised to find their wives so fat and fair and comely, for the chase was very scant at that time with the Feinn. The Feinn put before them that they would know what their wives were getting to make them thus, and when they went away again to the hunt they left Conan, one of themselves, at the house so that he might find this out. Conan kept a watch, and the food that they had was the hazel top boiled, and they were drinking the bree. It is said, too, that they used to wash themselves with this. The women understood that it was to watch themselves that Conan had been left at home, and there was great anger upon them. In the night when Conan lay down to sleep they tied his hair to two stakes which they put into the ground on each side of his head. Then the women went out to the front of the house and they struck their palms and cried 'the harryings' with great lamenting till they wakened Conan. Conan sprang on his feet with great haste, but he left part of the hair and of the skin of his head fast to the stakes. When Conan got the women within, he set fire to green heather and grey faggots in front of the house, so that he might kill the women with the smoke.

The Feinn were at this time in the Island of Skye, opposite to the house of Farabheil on the other side of Caol Reathainn, and when they saw the fire and the smoke rising up they called out loudly, striking their left hands on the fronts of their faces (foreheads) with their eyes on the sky. They ran to succour their set of wives, but the strait was between them; but with their spears they leaped the strait all but one, the son of Reathainn. The son of Reathainn fell in the strait, and he was drowned, and from that day till this day 'the Strait of Reathainn' has stuck as a name to the strait.

Valour swiftly for the women of the Feinn, And each one leapt on the point of his spear, But they left the son of Reathainn in the strait.

By good fortune the women all came through it but one or 
two of them, for the Feinn made mighty running to aid them. The Feinn were in great wrath with Conan for what he had done, and they caught him to put him to death. Conan asked as a favour that his head should be taken off him with Macan-Luinn, the sword of Fionn mac Cumhail, that would not leave a shred behind it, and that his own son Garabh should smite him on the thigh of Fionn. This was allowed him, but first seven grey hides and seven faggots of firewood and seven 'tirinn' of green turf were laid on the top of Fionn's thigh. Then the head of Conan was laid on that and Garabh his son struck the head off him with Mac-an-Luinn.

The crosses in the palm were not more numerous

Than the severed veins in the thigh of Fionn.

Then Garabh asked them where were the Feinn, for he had become mad, and they said to him that they were down below him. Then he went down till he reached the sea, and he lashed at the sea till he drowned himself in it.

Note.-The above version of this legend was taken down in the Island of Islay in 1860 ; another version, taken down in the Island of Skye in 1861, has it that 'Garabh' was the man left with the women, but does not give the reason for his being so left behind. According to the Skye version Garabh's petition was that Oscar, the son of Ossian, should cut off his head. A certain plausibility is given to the Islay version by the character commonly assigned to Conan of being rash and cross-tempered. The closing incidents, the madness and the beating of the waves and finally being drowned by them, are also attributed to Cuchulainn after he had killed in single fight his only and unknown son Connlaoch.

[The above tale may be compared with the poem which follows.-ED.] 